\title{
Optimáló módszerek alkalmazhatósága járműipari gumitermékek tervezésében
}

\section{Applicability of Optimization Methods in the Design of Automotive Rubber Products}

\author{
D. HURI ${ }^{1,2}$
}

1PhD-hallgató, Debreceni Egyetem, Informatikai Tudományok Doktori Iskola, 4028 Debrecen, Kassai út 26. 2tanársegéd, Debreceni Egyetem, Műszaki Kar, Gépészmérnöki Tanszék, 4028 Debrecen, Ótemető u. 2-4. huri.david@eng.unideb.hu,

Absztrakt. A gumitermékek tervezése során a velük szemben támasztott követelmények teljesítése céljából általánosan használt a méret, az alak vagy a topológia optimálási módszer. A vizsgált termék alakja a legtöbb esetben igen bonyolult, továbbá müködése közben érintkezésbe lép egyéb alkatrészekkel is. Jellemzően nagy deformációnak van kitéve, melyre a gumi alapanyag erősen nemlineáris tulajdonságot mutat. Ezen feladat analitikus megoldására nincs lehetôség ezért azt numerikus úton kell keresni, melynek futtatása igen időigényes folyamat. Ebből adódik a kutatásom célja, mely a különböző optimálási eljárások hatékonyságának és számítási költségének összehasonlítása. Jelen dolgozat célja az elérhető optimáló algoritmusok alkalmazási lehetőségeinek felkutatása jármüipari gumitermékek alakoptimálására. Ismertetésre kerül több helyettesítő modellen végzett optimum kereső eljárás továbbá számos direkt kereső módszer is.

Kulcsszavak: gumirugó, alakoptimálás, VEM, direkt kereső algoritmusok, helyettesítő modellezés

Abstract. Size, shape or topology optimization are widely used to fulfil the requirements in the design process of rubber products. In many cases, the shape of the product is very complex and comes into contact with other components during operation. It is commonly subjected to large deformation for which the rubber shows strongly nonlinear behaviour. For this complex problem analytical solution is not available, thus finite element method could be used in which the analysis running is a time consuming process. The object of my research is to compare the efficiency and computational cost of different optimization algorithms. This article focuses on the applicability of various optimization methods in the field of automotive rubber goods. Direct search optimization and surrogate model optimization methods will be introduced.

Keywords: rubber bumper, shape optimization, FEM, direct optimisation, surrogate modelling

\section{Bevezetés}

Doktori kutatásomban gumiütközők gépészeti tervezési folyamatába integrált optimáló algoritmus fejlesztésével foglalkozom. A termék tehergépjárművek légrugójában alkalmazott, ahol a nyomó 
igénybevételre adott erő-elmozdulás karakterisztika az egyik legfontosabb vele szemben támasztott műszaki működési követelmény. Számos esetben ennek meghatározása vevői követelményből adódik, melynek teljesítése iterációs tervezési folyamathoz vezet. A tervezőmérnökök leggyakrabban a termék alakjának módosításával érik el a kívánt múködési karakterisztikát. Ezt a folyamatot alakoptimalizálásnak nevezzük, melynek legegyszerűbb megoldási módja, ha egy úgynevezett „what if” tanulmánnyal a tervezőmérnök tapasztalatára támaszkodva, próbálgatással történik az optimális geometria meghatározása. A nagy alakváltozást leíró kontinuummechanikai háttérnek, valamint a rendelkezésre álló hiperelasztikus anyagmodellnek köszönhetően a próbálgatás történhet végeselemes analízis alkalmazásával. Ha lehetőség van a geometria létrehozásától az eredmények kinyeréséig parametrizálni a folyamatot, akkor automatizálható az optimális kialakítás megtalálásához vezető út. Ebben az esetben lehetőség van számos optimalizáló módszert bevetni a tervezési folyamatba. Ennek előnye, hogy az optimális kialakítás megtalálása időben sokkal inkább tervezhetővé válik, és bár számításigénye költséges, de az jelentős mennyiségű mérnöki munkaórát vált ki. Jelen dolgozat célja áttekinteni milyen eljárások alkalmazottak az iterációs gépészeti tervezés folyamatában, különös tekintettel a műszaki gumitermékek alakoptimalizálásának területén.

\section{Gépészeti feladatok optimálása}

Az optimáló módszerek között megkülönböztetünk lokális vagy globális optimum kereső eljárásokat. A lokális kereső eljárások többsége megköveteli a gradiens számítását míg a globális optimum kereső eljárások többsége direkt, azaz a gradiens mentes optimalizáló algoritmusok közé tartozik. Ezen eljárások a függvény értékét használják, ezért nem szükséges annak analitikus úton történő előállítása, ily módon akár „black box" modellek is vizsgálhatók, ezáltal alkalmasak az általam vizsgált feladatra is. A direkt optimáló algoritmusok közé tartozik a lokalizált sztochasztikus keresés, Nelder-Mead módszer (szimplex módszer), szimulált hűtés (Simulated Annealing), alagutazás (Tunneling) és még számos egyéb módszer.

Lipták egy hegesztett szerkezet tervezési problémáját írja le, amelynek célja egy egyoldalról merevített lemez kialakításának optimalizálása. Három optimalizáló algoritmus került bevezetésre, nevezetesen egy komplex, differenciális evolúció és részecske-raj (Particle swarm optimization, PSO) alapú. Az eredmények azt mutatták, hogy a PSO módszer egy jó kompromisszum a célfüggvény kiértékelések száma és a biztonság között. A differenciális evolúciós algoritmusa 1400 iterációt igényelt, míg a részecske raj algoritmusa csak 400-at [1]. Luus-Jaakola lokális kereső algoritmust alkalmazott exponenciálisan csökkenő keresési téren generált álvéletlen (pszeudo-random) számok segítségével. $\mathrm{Az}$ algoritmus hatékonyságának tesztelésére matematikai, kémiai és mérnöki feladatok kerültek vizsgálatra. Az optimális értéket minden esetben 0,1\%-on belül és kevesebb mint 3000 függvény számítással határozta meg az algoritmus [2].

Azokat a metamodell módszereket, melyeket költséges szimulációt igénylő mérnöki feladatok helyettesítésére alkalmaznak, az angol szakirodalmi nyelv „Surrogate models” gyűjtőszóval említi [3]. Általában a cél az eredeti modellt folytonosan leíró és jól közelítő helyettesítő modell kiválasztása, mely az eredetinél mindenképpen kisebb számítási költséggel hívható. Többfajta metamodell ismert, az egyszerű és adaptív válaszfelület módszer, a kriging módszer, a radiális bázisfüggvény, többváltozós 
adaptív spline regresszió, neurális hálók, vagy a szupport vektor gépek [4]. A Genetic Aggregation (genetikus egyesülés) algoritmus által létrehozott válaszfelület keletkezhet egyetlen válaszfelületből, vagy számos különböző válaszfelület (Full 2nd-Order Polynomials, Non-Parametric Regression, Kriging, és Moving Least Squares) súlyozott kombinációjaként [5]-[7].

\section{Gumitermékek alakoptimálása}

Számos kutató végzett alakoptimalizálást próbálgatással, vagy úgynevezett „trial and error” vagy „what if” eljárás alkalmazásával. Egy ilyen dolgozat a lengéscsillapítóban található rezgéscsillapító gumiszilent kifáradásának okát vizsgálja. A vizsgálati eredmények azt mutatták, hogy a nagy nyúlást szenvedő zónák mentén fog az alkatrész kifáradni. A nyúlásértékeket az alkatrész alakjának módosításával, valamint a gumi Shore keménységének növelésével érték el, amiknek hatására kifáradásra kevésbe lett veszélyes az alkatrész [8]. Az egyik tanulmány bemutatja egy homokinetikus féltengely csuklóját védő gumiharangjának vizsgálatát és iterációs optimálását. A végeselemes vizsgálatokkal a mérnököknek sikerült előre letesztelni közel hatvan féle módosított geometriájú gumiharang deformációját és feszültségviszonyát. Végeredményként sikerült egy kisebb méretű, kisebb feszültségi állapotú, és önmagával kevésbé érintkező kialakítást megalkotni [9].

Kaya és társai egy gumi persely alakoptimalizálását vizsgálták differenciál evolúciós módszer alkalmazásával. Az optimalizálás célfüggvénye a gumipersely egy előre meghatározott erő-elmozdulás jelleggörbéjének teljesítése. A célfüggvény az Abaqus szoftverben három geometriai változóval felépített végeselemes modell segítségével került meghatározásra. A cikk alapján az alakoptimalizálási feladat globális optimumának megtalálására hatékony eszköznek bizonyult a differenciál evolúció és végeselem módszer kombinálása [10]. Egy kisteherautóban alkalmazott gumiütköző alakjának optimalizálására genetikus algoritmus (GA) és végeselemes módszer került alkalmazásra. Általános feladatok esetén GA egy hatékony optimalizáló eljárás, azonban a legnagyobb hátrányuk mérnöki feladatok alkalmazása során az időigényes felhasználásuk [11].

Többcélú optimalizálás lett megoldva egy személygépjármű felfüggesztésében megtalálható gumipersely előírt sugár, tengely és torziós irányú merevégségének elérése céljából. A célfüggvény gyorsabb számítása érdekében analitikus képletek kerültek meghatározásra. Matlab környezetbe integrált szekvenciális kvadratikus többváltozós optimáló algoritmus került alkalmazásra [12]. Kim egy motortartó gumibak paraméter optimalizálását végezte el. A feladat célja négy geometriai méret változtatásával minimálisra csökkenteni a termék előírt különböző merevségei és az aktuális kialakítás közötti merevségek különbségét. A célfüggvény ezen különbségek szignifikanciája alapján súlyozott összegként állt elő. Optimáló algoritmusként a másodrendű konvergenciával rendelkező Fletcher módszer, míg a kényszerek érvényesítésére a Powel féle büntető tag [13] került hozzáadásra a célfüggvény értékéhez. A módszer sikeres a termék alakjának koncepcionális tervezésére [14].

\section{Metamodellel végzett optimáló módszerek}

Mankovits értekezésében gumiütközők alakoptimalizálásával foglalkozik, ahol a végeselemes szimulációkkal történt adatkinyerés az optimalizáló algoritmustól független. Az optimális alak 
meghatározásához kizárólag egy célfüggvény került meghatározásra. A tervezési térből kinyert dizájn változatok, mint tanulópontok kerültek felhasználásra. A további konstrukciók célfüggvényre adott értékének meghatározására gépi tanulási módszerrel felvett helyettesítő modell került alkalmazásra. Ezen metamodell segítségével az optimális kialakítás meghatározásra került [15]-[18].

Previati egy autóipari gumitermék ötváltozós alakoptimalizálását vizsgálta. Az optimálás célfüggvényének a gumipersely tömegét és élettartamát vette, kényszerként pedig a persely merevségét, valamint az anyagban ébredő maximális Cauchy feszültséget. Végeselemes vizsgálat került futtatásra négy különböző anyagmodellel egyenként 200 különböző variációval. Az így futtatott szimulációk használatával interpolációs függvények kerültek illesztésre az optimalizálási feladat be- és kimenetei közé [19]. Li egy genetikus neurális hálón és végeselemes módszeren alapuló paraméter optimálási módszert javasolt gumirögzítők tervezéséhez. Az MSC.MARC végeselemes szoftver segítségével meghatározásra került a termék három fő iránya menti merevsége. Ortogonális kísérleti tábla lett alkalmazva a tanuló pontok megtervezésére, melyeket felhasználva a neurális háló tanítása hiba-visszaterjesztéssel történt. Az optimális kialakítás validálására prototípus került gyártásra [20].

A személygépjárművek hűtőrendszerét rögzítő gumi rezgéscsillapító többcélú alakoptimalizálását vizsgálták az élettartam és rezgéscsillapító képesség maximalizálását célul kitűzve. Feltételként adott volt az alsó rezgéscsillapító beszerelésből és a szerkezet önsúlyából adódó maximális deformációja. Ezen értékek meghatározása a HyperMesh, Abaqus, MATLAB és MSC.Fatigue CAE szoftverek integrálását követelte meg. A teljes folyamat automatizálása egy a kereskedelmi forgalomban kapható folyamat integráló és optimum kereső (PIDO) szoftver a PIAnO alkalmazásával történt. CAE szoftverek közötti kommunikáció létrehozásával a komplex tervezési folyamat ciklusideje lecsökkent. A PIAnOban rendelkezésre álló regresszió alapú optimalizáló eljárás segítségével sikerült a rezgéscsillapító gumi optimális alakját meghatározni két különböző típusú hűtőrendszerre [21]

\section{Összefoglalás}

Az elvégzett irodalomfeldolgozás alapján számos eljárást sikerült áttekintenem gumitermékek alakoptimálási feladatának megoldására. Az ismertetett eljárások iterációs igénye számos esetben nem volt leírva, így egy gyakorló tervezőmérnök számára nem áll rendelkezésére információ arról, hogy a különböző algoritmusok mennyire költségigényesek gumitermékek alakoptimálási feladatainak megoldása során. A metamodellen végzett eljárások esetében minden esetben szükséges a kapott optimális kialakítás validálása, mely így utólagos emberi beavatkozást igényel. Az ismertetett eljárások a legtöbb esetben az alkalmazott algoritmus paramétereinek beállításait nem ismertetik és változtatásuk hatását nem vizsgálják pontosság és költséghatékonyság szempontjából.

\section{Köszönetnyilvánítás}

A tanulmány alapjául szolgáló kutatást részben az Innovációs és Technológiai Minisztérium által meghirdetett Tématerületi Kiválósági Program ED_18-1-2019-0028 számon támogatta, a Debreceni Egyetem (Járműipar) tématerületi programja keretében, másik részben pedig az Innovációs és 
International Journal of Engineering and Management Sciences (IJEMS) Vol. 5. (2020). No. 2

DOI: 10.21791/IJEMS.2020.2.41.

Technológiai Minisztérium ÚNKP-19-3 kódszámú Új Nemzeti Kiválóság Programjának szakmai támogatásával készült.

\section{Hivatkozások}

[1] L. Gábor, “Optimáló algoritmusok összehasonlítása," X. Fiatal Múszakiak Tudományos Ülésszaka, no. 1, pp. 255-258, 2005.

[2] R. Luus and T. H. I. Jaakola, "Optimization by direct search and systematic reduction of the size of search region,” AIChE J., vol. 19, no. 4, pp. 760-766, Jul. 1973.

[3] A. I. J. Forrester, A. Sóbester, and A. J. Keane, Engineering Design via Surrogate Modelling. Oxford, UK: Wiley, 2008.

[4] C. Erdősné Sélley, G. Gyurecz, J. Janik, and G. Körtélyesi, Mérnöki Optimalizáció. Typotex, 2012.

[5] E. Acar and E. Acar, "Various approaches for constructing an ensemble of metamodels using local measures,” vol. 42, pp. 879-896, 2010.

[6] S. Wang, G. Jian, J. Xiao, J. Wen, and Z. Zhang, "Optimization investigation on configuration parameters of spiral-wound heat exchanger using Genetic Aggregation response surface and Multi-Objective Genetic Algorithm," Appl. Therm. Eng., vol. 119, pp. 603-609, 2017.

[7] F. A. C. Viana, R. T. Haftka, and V. Steffen, "Multiple surrogates: how cross-validation errors can help us to obtain the best predictor," Struct. Multidiscip. Optim., vol. 39, no. 4, pp. 439-457, Oct. 2009.

[8] H. D. Gurav, S. B. Sanap, and B. Duggirala, "Non-Linear Finite Element Analysis of Rubber Bush for 2-Wheeler Rear Shock Absorber for Prediction of Fatigue Life," 2015.

[9] R. Kennison, "Nonlinear Simulation Helps Design Longer Lasting CV Boots," Simulating reality, MSC Softw. Mag. Vol. II, vol. 2, pp. 18-19, 2012.

[10] N. Kaya, "Shape optimization of rubber bushing using differential evolution algorithm," Sci. World J., vol. 2014, 2014.

[11] M. Shafigh, B. Dehghan-Manshadi, and B. Khosravi, "Using a genetic algorithm in shape optimization of the front axle bump stop for a new pickup vehicle (ZAMAYD-24F)," WIT Trans. Built Environ., vol. 80, pp. 311-321, 2005.

[12] J. Rivas-Torres, J. C. Tudon-Martinez, J. de-J. Lozoya-Santos, R. A. Ramirez-Mendoza, and A. Spaggiari, "Analytical Design and Optimization of an Automotive Rubber Bushing," Shock Vib., vol. 2019, pp. 1-13, Mar. 2019.

[13] J. N. Siddall, Optimal engineering design : principles and applications. New York: Marcel Dekker, 1982.

[14] J. J. Kim and H. Y. Kim, "Shape design of an engine mount by a method of parameter optimization," Comput. Struct., vol. 65, no. 5, pp. 725-731, Dec. 1997. 
[15] T. Mankovits, I. Kocsis, T. Portik, T. Szabó, and I. Páczelt, "Shape design of rubber part using FEM," Int. Rev. Appl. Sci. Eng., vol. 4, no. 1, pp. 85-94, 2013.

[16] T. Mankovits, T. Szabo, I. Kocsis, and I. Paczelt, "Optimization of the shape of axi-symmetric rubber bumpers," Stroj. Vestnik/Journal Mech. Eng., vol. 60, no. 1, pp. 61-71, 2014.

[17] T. Mankovits and T. Szabó, "Nem-lineáris VEM program gyakorlati alkalmazása gumialkatrészekre," Multidiszcip. Tudományok A Miskolci Egy. Közleménye 2, 2012.

[18] T. Mankovits and T. Szabó, "Finite Element Analysis of Rubber Bumper Used in Air-springs," Procedia Eng., vol. 48, pp. 388-395, 2012.

[19] G. Previati, M. Kaliske, M. Gobbi, and G. Mastinu, "Structural optimization of a rubber bushing for automotive suspension," in Constitutive Models for Rubber VII, CRC Press, 2011, pp. 307-312.

[20] Q. Li, J. Zhao, B. Zhao, and X. Zhu, "Parameter Optimization of Rubber Mounts Based on Finite Element Analysis and Genetic Neural Network," J. Macromol. Sci. Part A, vol. 46, no. 2, pp. 186192, Dec. 2008.

[21] C.-H. Park, H.-J. Shim, D.-H. Choi, J.-K. Kim, and S.-M. Lee, "Shape optimization of rubber isolators in automotive cooling modules for the maximization of vibration isolation and fatigue life," Int. J. Automot. Technol., vol. 13, no. 1, pp. 61-75, Jan. 2012. 